\title{
The Use of Local Literary Texts as Reading Materials in English Language Classrooms: An Analysis of Teachers' Perspectives
}

\author{
Muhammad Shahril Haja Mohaideen \\ Universiti Sultan Zainal Abidin, Kuala Nerus, Terengganu, Malaysia \\ https://orcid.org/0000-0003-4811-8297 \\ Hanita Hanim Ismail \\ Universiti Kebangsaan Malaysia, Bangi, Malaysia \\ https://orcid.org/0000-0003-3121-8822 \\ Radzuwan Ab Rashid \\ Universiti Sultan Zainal Abidin, Kuala Nerus, Terengganu, Malaysia \\ https:/ / orcid.org/0000-0002-1334-6268
}

\begin{abstract}
It is common for Malaysian primary school pupils to have difficulties in reading English texts. One of its factors concerns text selection. Hence, a careful selection of the text is needed to ease their reading experience in ESL (English as Second Language) classrooms. This study explored teachers' perceptions on literary text selection for Malaysian primary schools. An online questionnaire was distributed to gauge teachers' perceptions on the current materials in terms of its impact on the students and lesson effectiveness. Respondents were 34 teachers of Years 4 to 6 in primary schools in Terengganu, the east coast Malaysia. Data analysis revealed that the teachers perceive local materials as more relatable to pupils in comparison to the foreign texts. The local texts are also perceived to have greater impacts on the students and lessons despite doubts remaining within the autonomy of this selection. This study is hoped to be helpful to the Ministry of Education and the teaching community in improving text selection in the future.
\end{abstract}

Keywords: ESL; KSSR; literature; Malaysian primary school pupils; text selection

\section{Introduction}

Malaysian national primary schools have employed the English Language Syllabus for Primary Schools (KBSR) since 1983. However, due to arguable 
weaknesses within the previous syllabus, the Malaysian Ministry of Education (MoE) reinforced the implementation of Standard Curriculum for Primary Schools (KSSR) syllabus starting 2011 with the aim to overcome shortcomings in the older system and introduced literature into the assessment equation (Peekabook, 2013; Rashid, Abdul Rahman \& Yunus, 2017). This is in line with the 2nd Shift in the Malaysian Education Blueprint 2013-2025 (MEB) where one of its emphases focuses on proficiency for both Bahasa Malaysia and English language. Pupils are further exposed to the English language with the introduction of literature components in both Primary and Secondary levels, with hope that they are proficient in English by the end of their six-year primary schooling (MoE, 2013).

Research has shown an association between improved communication skills among students and the use of exercises which are based on literary reading materials (e.g. Akyel \& Yalcin, 1990; Rashid, 2011). As such, one cannot deny a plausible reason for incorporating literature as part of the Malaysian KSSR syllabus, particularly those focusing on Malaysian primary pupils between Year 4 and Year 6. The introduction of literature in KSSR was observed to have paved new ways for learning English as a Second Language (ESL) (Sulaiman, Mohd Ayub \& Sulaiman 2015). However, Kaur and Mahmoor (2014) suggest the reconceptualization of the English syllabus, particularly in the role of Literature. They argue that it should serve not only as a tool for proficiency but also as an agent for globalized change that enriches the knowledge of heritage and culture. Ironically, it was reported by The National Union of Teaching Profession (NUTP) that the level of English proficiency among primary school pupils has since declined even after the incorporation of literature as part of the syllabus (Ain, 2019). In fact, the standard of language learning was seen deteriorating, with Malaysian English language proficiency plummeting from 13th place to the 22nd place in the EF English Proficiency Index for non-native speakers (Aziz, 2018; Aziz, Rashid \& Zainudin, 2018). This was highlighted by Azman (2016) who observed a general dilemma with achieving the minimum level of competency with English. Unless this aspect is further scrutinized, the problems will prolong, causing dire dilemmas in the local learning scenario.

\section{Table 1. Literary reading items used in Malaysian Primary Schools}

\begin{tabular}{llll}
\hline Year & Short Stories & Graphic Novels & Poems \\
\hline 4 & $\begin{array}{l}\text { "The King of Kites" by } \\
\text { Judith Heneghan }\end{array}$ & $\begin{array}{l}\text { "The Jungle Book" by } \\
\text { Rudyard Kipling }\end{array}$ & $\begin{array}{l}\text { "Anthology of Poems for } \\
\text { Year 4,5 and 6" Compiled } \\
\text { by John Foster }\end{array}$ \\
5 & $\begin{array}{l}\text { "And Something Weird } \\
\text { Happened..." by Pamela }\end{array}$ & $\begin{array}{l}\text { "Gulliver's Travels" by } \\
\text { Jushby }\end{array}$ & \\
6 & $\begin{array}{l}\text { "Akbar's Dream" by Swift } \\
\text { Jane Langford }\end{array}$ & $\begin{array}{l}\text { "The Wizard of Oz" by } \\
\text { Frank Baum }\end{array}$ & \\
\hline
\end{tabular}

Since 2016, primary schools incorporate a selection of literary readings, which includes a book on poems, a graphic novel and a short story for students of Years 4, 5 and 6, as listed in Table 1 . The pupils are required to read folktale-themed stories and classic novels that are abridged in version while the poems are a 
compilation, which include various themes ranging from appreciating nature to honouring family. What is observed is an incorporation of the three genres (i.e. poetry, prose and drama) at appreciating literature as a whole. Since literature is a powerful agent at shaping minds into habits (Ismail, 2019), one can imagine the impact from choosing appropriately suitable literary materials on different aspects of social training.

\subsection{Research gap and Objectives}

Malaysian primary school pupils are noted to be generally struggling with ESL readings with a common traceable factor which is an issue of text selection (e.g. Puteh, Mohd Zin \& Ismail, 2012; Abdul Hamid \& Mohd Shah, 2017; Mihat, Azman \& Or, 2018; Mustaffar et al., 2019; Muhammad, Latiff Azmi \& Hassan, 2020; Thirunavukarasu \& Raja Harun, 2021). Malaysian students continue to face difficulty when dealing with foreign cultural elements, particularly in its comprehension. In fact, Nambiar et al. (2020) indicate that local culture-based reading materials help the forging of confidence in English of which helps generate sustainable means for encouraging the development of local instructional materials (Lasekan \& Godoy, 2020).While there are other papers focusing on perceptions regarding text selection in the literature component (e.g. Rashid, Vethamani, \& Rahman, 2010; Mohd Naser \& Abd Aziz, 2017; Rashid, Abd Rahman, \& Ismail, 2020) and responses on the re-introduction of English Literature as part of the school syllabus (Suliman \& Yunus, 2014a; Suliman \& Yunus, 2014b), none has yet looked into perceptions on its effectiveness, particularly those used for primary school students. As such, this factor appropriated the rationale of this research in order to evaluate the perceived effectiveness of the current selection of literary texts used in the teaching of literature in Malaysian primary school classrooms, specifically taking into consideration teachers' perception on the choices of literary materials, as provided by the Ministry.

While the more urban primary schools have lesser problems at using English literary texts as classrooms teaching materials, rural areas are challenged in terms of pupils' reading exposure and interest. This study sought the perspectives of teachers in Kuala Nerus which is the youngest district in Terengganu, a state in the eastern part of Malaysia. Despite experiencing urbanization and development, Terengganu is made up of rural areas which are least exposed to development compared to the urban areas (Zulaily et al., 2017) with $16 \%$ of its schools performing below $85 \%$ of the English literacy rate (Azman, 2016). In such a case, these primary school students are not only exposed to foreign culture but also remain anxious towards the use of foreign language, which is a universal phenomenon (e.g. Saito, Horwitz \& Garza, 1999). To date, Kuala Nerus is generally not as developed as its urban counterparts. Most schools in the area are located in nearby villages and are not as well equipped with facilities as schools in urban areas in Terengganu. The majority of pupils in this area are not as exposed to the English language as those in the urban areas and are more accustomed to the Malay language instead. 
This study was carried out to answer the following research questions:

1. How do teachers perceive the effectiveness of the prescribed literary texts for the teaching of literature in Malaysian primary schools?

2. How do teachers perceive the use of foreign as opposed to local literary texts for the teaching of literature?

Answering these questions provides the significance of this study in line with Bousbai's (2014) emphasis for considering text selection at ensuring lesson success. Not only text selection helps effective teaching experience in order to increase English proficiency among primary school students but also serves the interest of public stake-holders such as the MoE, parents, students and the public in general. Reassessing the effectiveness of local as opposed to foreign literary texts provides the basis for the implementation of a more concrete and effective literature module. This in turn will raise the level of English language proficiency among Malaysian primary school pupils, enhancing their use of English at a higher level as compared to their predecessors which in turn will help to raise their marketability and thus increase the quality of the Malaysian workforce.

\section{Related Works}

A review of the literature was conducted to provide a background understanding of the research context and issues related to the Malaysian education system as well as its concerns. Using literary texts as part of English classroom activities plays an important role in learning English language, especially in enhancing communication competence, raising cultural awareness and generating motivation among students (Khan \& Alasmari, 2018). In fact, Bousbai (2014) emphasizes that the choice of text is the most crucial element in literature courses, echoed by Lima (2010) who suggested a need of five criteria to be considered before a text is selected. This is detailed by Prowse (2002) as: (1) students' choice, (2) students' ease, (3) student engagement, (4) students' comprehension and (5) teacher's participation. Bousbai (2014) also highlighted some pedagogical criteria in selecting materials which are learner's linguistic proficiency, learner's cultural background and learner's literary background.

While text selection is an important stage during the pre-lesson, the evaluation stage is equally needed for two reasons - not only it hinders repetition in faulty selection, it also reinforces positive lessons from the materials to be employed in the following lessons. Yet, most teachers are not even aware of the need to continuously engage in text evaluation (Mukundan, 2007). Bousbai (2014) urged for an evaluation and classification of these materials as according to types of students, and its relevance, depending on the general needs and objectives of the course. In the Malaysian context, text evaluation is important in order to provide feedback to the central authority (i.e. MoE) for revision processes to be considered (Mukundan, 2007) and in this case with the consistent changes of literary textbooks provided by the Ministry for the use of teachers and students, the Ministry has the opportunity to rectify and instil elements that can help the materials work more effectively. While the issue of appropriate text selection has long been discussed at local level (e.g. Ghazali, Setia, Muthusamy \& Jusoff, 2009; Lim, 2018), it is so crucial to provide insights into the improvement made in order 
to facilitate progress to suit students' needs. There are studies that specifically look into students' perceptions with regards to text selections for the literature component, which interestingly pointed at a tendency of rote learning (e.g. Mohd Naser \& Abd Aziz, 2017).

Possible criteria for text selection as classroom and extensive reading include giving freedom to the pupils to choose the text they want to read (Prowse, 2002; Waring, 2008) and recommending reading materials that are available as well as those that are culturally and linguistically appropriate. Researchers argue that materials selected for the ESL/EFL reading class ought to satisfy students' interests. Lotherington-Woloszyn (1988), for example, highlighted that learners find texts as uninteresting for failing to engage with them and turning things relatable, despite the level of text readability. It is not about ease in reading; learners look forward to things that they can connect with. Other research studies suggest text selection to be based on students' interest (e.g. Papalia, 1987; Sewell, 2003). Brumfit's (1985) criteria for text selection are also useful that the selection should consider suitable linguistic level, cultural and social expectations of different groups of learners, and the length of the text.

In Malaysia, material selection is shouldered by MoE. As such, the weight of such responsibility should enable text engagement with readers (cognitively and effectively). However, teachers also play a crucial role in selecting texts, particularly in considering students' perceptions and interests.

\section{Methods}

This quantitative research is based on data collected using a set of questionnaire which was distributed among ESL primary school teachers who teach literature from Year 4 until Year 6 in Kuala Nerus. Respondents were selected using snowball sampling, consisting of 33 female teachers and one male teacher. Snowball sampling allows the use of "initial data sources as the basis for finding additional data" (Given, 2008, p.800). These respondents were made up of 26 teachers with experience in teaching English for over 10 years where three teachers each with teaching experience between three to five years and six to nine years, and two teachers who had been teaching English for less than three years. However only 10 teachers have been teaching English literature for more than 10 years with 24 of them teaching English literature for less than 10 years. Majority of the teachers $(n=11)$ have only been teaching English for less than three years. It is a common practice within the Malaysian school system to have overlapping scope of teaching between the three years (Year 4-6) due to limited number of manpower and issues of teaching specialization, especially in the east coast. Despite the small sample size which would not allow generalizability, its data allows transferability to other similar contexts. The background information of the respondents is summarised in Table 2 below. 
Table 2. Study Sample

\begin{tabular}{lllll}
\hline Teaching & & $>10$ year & $3-10$ years & $<3$ years \\
\hline \multicolumn{2}{l}{ Teaching experience (years) } & 26 & 6 & 2 \\
Teaching responsibilities & Year 4 & 13 & 3 & 1 \\
& Year 5 & 15 & 1 & - \\
& Year 6 & 11 & 1 & - \\
\hline
\end{tabular}

Questions appear in a 5-point Likert scale, ranging from one (for Strongly Disagree) to five (Strongly Agree), which enables adjacent options to be less radically different (or more gradually different) from each other. Respondents are more independent at picking the most precise option (which he/she prefers most), instead of picking some 'nearby' or 'close' option (Dawes, 2018). The questionnaire is divided into three sections - Section A (demographics), Section B (the perceived effectiveness of the literary texts used) and Section $C$ (teachers' perceptions on the use of local/foreign literary texts). There are nine questions each in Section B and C with each section focusing on three aspects based on the research objectives. Precision was the ultimate aim when designing the questionnaire in order to avoid burdening the respondents and to ensure well thought responses. It is commonly agreed by quantitative researchers that fewer items result in lower burden and higher data quality (e.g. Heberlein \& Baumgartner, 1978).

In order to ensure face and content validity, three experts in ESL fields were appointed to review the questionnaire. Expert evaluation includes reviewing the coverage of the questions in relation to the research questions and commenting on the relevance of the questions. Upon receiving comments from the experts, the items were then revised, and reworded.

After drafting the questionnaire, it was then converted into a Google form as an alternative to the more traditional means of questionnaire as it is paperless, cost efficient and can be distributed across a large geographical area. As put by Wright (2017), online questionnaires aid tremendously in access to unique populations and saving time and cost, which in this case was relevant as the schools in the district were in remote locations and would require a lot of effort to be reached physically. The researchers contacted school headmasters who later distributed the link to potential respondents in order to maximise reachability. Along with the questionnaire, a consent form was also attached for the respondents to fill in in order to ensure ethics at implementing anonymity and minimizing prejudice or external pressure. Informed consent ensures that potential respondents are aware of the nature of the research they are participating in (Fischman, 2000).

In order to ensure efficiency in handling the data, responses were directed to the researchers' emails. The data were then analysed using the Statistical Package for Social Science (SPSS) Version 25 focusing on the frequencies, percentage and mean score in relevance to explore teachers' perception on the selected literary texts. The use of descriptive statistics provided simple summaries about the sample and 
enabled comparisons across people or other units (Trochim, 2020). The mean score was calculated by multiplying the total number of responses for each Likert scale category and averaging the resulting total to the range of the Likert scale which in this case, the value was 5 (e.g. Decker, 2018). This ensured that the final mean score resembles the score in the Likert scale result form.

\section{Findings and Discussions}

\subsection{Perceived Effectiveness of the Current Literary Texts}

In order to assess the perceived effectiveness of text selection, the researchers considered both perspectives - teachers' perspectives of text effectiveness - on pupils as well as their own teaching profession. The first three questions focused on the teacher's observation of text effectiveness through classroom involvement while understanding the texts. Based on the 34 responses, this section reveals a notable pattern in responses where the most frequent answers are either Neutral or Agree with the majority edging towards agreeing that the materials are effective for the students. Table 3 , for example, shows that while the teachers were divided in their observation of their pupils' level of understanding, a majority of them believe that their pupils participate in the classroom in their effort of understanding the meaning. Teachers' choice to posit neutrality in stance can be understood based on the researchers' observation on the local's perspective on matters. A neutral stance is most favourable in order to avoid conflict by projecting a non-partisan position on any matter, which otherwise, would appear to be offensive and/or non-conformist in nature. Similarly, it was also noted that regarding the students' participation in understanding the materials, $47 \%$ of the respondents agreed while $44 \%$ were neutral on their opinion with a score mean of 3.65. In fact, efforts are also seen in expressing themselves where pupils were observed to communicate with their peers when deciphering the texts. Majority teachers noted active collaborative effort was engaged since literary texts are known to demand another level of reading ability. An almost similar share of responses is mainly divided between Agree (53\%) and Neutral (41\%) in stance with a mean score of 3.65 .

Table 3. Perceived effectiveness of materials for students

\begin{tabular}{|c|c|c|c|c|c|c|c|}
\hline & Item & 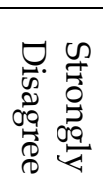 & 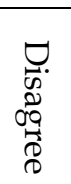 & 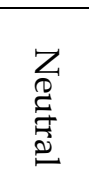 & $\begin{array}{c}\vec{D} \\
\stackrel{d}{0} \\
\mathbb{D} \\
D\end{array}$ & 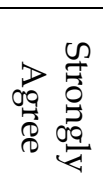 & 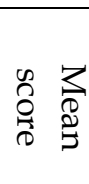 \\
\hline B1 & $\begin{array}{l}\text { Students actively participate } \\
\text { in the process of } \\
\text { understanding the meaning } \\
\text { of materials }\end{array}$ & $\begin{array}{l}0 \% \\
(0)\end{array}$ & $\begin{array}{l}0 \% \\
(0)\end{array}$ & $\begin{array}{l}44 \% \\
(15)\end{array}$ & $\begin{array}{l}47 \% \\
(16)\end{array}$ & $\begin{array}{l}9 \% \\
(3)\end{array}$ & 3.65 \\
\hline B2 & $\begin{array}{l}\text { Students are stimulated to } \\
\text { work with classmates in } \\
\text { deciphering the literary item }\end{array}$ & $\begin{array}{l}0 \% \\
(0)\end{array}$ & $\begin{array}{l}0 \% \\
(0)\end{array}$ & $\begin{array}{l}41 \% \\
(14)\end{array}$ & $\begin{array}{l}53 \% \\
(18)\end{array}$ & $\begin{array}{l}6 \% \\
(2)\end{array}$ & 3.65 \\
\hline B3 & $\begin{array}{l}\text { The materials are able to } \\
\text { enhance more than one } \\
\text { language skills in the } \\
\text { students }\end{array}$ & $\begin{array}{l}0 \% \\
(0)\end{array}$ & $\begin{array}{l}0 \% \\
(0)\end{array}$ & $\begin{array}{c}27 \% \\
(9)\end{array}$ & $\begin{array}{l}68 \% \\
(23)\end{array}$ & $\begin{array}{l}6 \% \\
(2)\end{array}$ & 3.79 \\
\hline
\end{tabular}


While $68 \%$ agreed that the prescribed literature texts aid in enhancing students' language, only $27 \%$ were neutral when asked about the contribution of the selected texts at enhancing pupils' level of language skills, while none disagreed. At large, most appreciated the role that the selected literary texts had in enhancing the pupils' quality of language skills. This is crucial in showing that the selection was not a waste in terms of cost effectiveness and that it was a functional text material. This national concern over students' language proficiency has been repeatedly (re)expressed in studies, such as Ain (2019) and Aziz (2018), who cite the Malaysian score on the English language proficiency, which plummeted from 13th place to the 22nd place, dropping nine spots in the EF English Proficiency Index for non-native speakers.

On the aspect of teachers' perception on text effectiveness, findings from items B4-B6 (Table 4) reveals 53\% of the respondents agreed while $26 \%$ remained neutral on the ease of the materials in preparing for lessons. Regarding the role of the material at stimulating the use of target language, 65\% agreed that the materials provided assistance while $26 \%$ remained neutral. An almost similar pattern of response is also observed in item B7 on the effectiveness of the selected texts in supporting teaching objectives where $62 \%$ were in agreement while only $18 \%$ remained passive in their judgement. Table 4 shows the distribution of responses.

Table 4. Perceived Effectiveness of materials for teacher

\begin{tabular}{|c|c|c|c|c|c|c|c|}
\hline Item & & 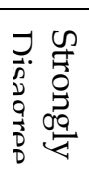 & 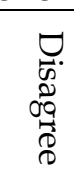 & 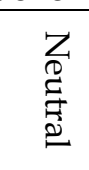 & $\begin{array}{c}\vec{D} \\
0 \\
0 \\
0 \\
0\end{array}$ & 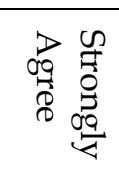 & $\begin{array}{ll} & 0 \\
0 & 0 \\
\tilde{\sigma} & 0 \\
0\end{array}$ \\
\hline B4 & $\begin{array}{l}\text { Teachers can plan a lesson } \\
\text { easily with the provided } \\
\text { materials }\end{array}$ & $\begin{array}{l}0 \% \\
(0)\end{array}$ & $\begin{array}{l}6 \% \\
(2)\end{array}$ & $\begin{array}{l}26 \% \\
(9)\end{array}$ & $\begin{array}{l}53 \% \\
(18)\end{array}$ & $\begin{array}{l}15 \% \\
(5)\end{array}$ & 3.76 \\
\hline B5 & $\begin{array}{l}\text { Literary materials help } \\
\text { teachers to stimulate use of } \\
\text { target language }\end{array}$ & $\begin{array}{l}0 \% \\
(0)\end{array}$ & $\begin{array}{l}0 \% \\
(0)\end{array}$ & $\begin{array}{l}26 \% \\
(9)\end{array}$ & $\begin{array}{l}65 \% \\
(22)\end{array}$ & $9 \%(3)$ & 3.82 \\
\hline B6 & $\begin{array}{l}\text { Materials used support the } \\
\text { teaching objectives of the } \\
\text { teacher }\end{array}$ & $\begin{array}{l}0 \% \\
(0)\end{array}$ & $\begin{array}{l}0 \% \\
(0)\end{array}$ & $\begin{array}{l}18 \% \\
(6)\end{array}$ & $\begin{array}{l}62 \% \\
(21)\end{array}$ & $\begin{array}{l}21 \% \\
(7)\end{array}$ & 4.03 \\
\hline
\end{tabular}

It can also be seen that most respondents could not agree that planning a lesson is easy with the provided materials based on B8 and B4 despite $61.8 \%$ of the respondents mostly agreeing that the materials support the objectives set by them as stated in C6. This conflicting finding shows that while the intent of the material is in the right direction, the materials itself do not make life easy for the teachers in constructing the lessons hence action is required by the $\mathrm{MoE}$, as suggested by Mukundan (2007) where there is a clear need to reconsider the materials for revision. The failure to do so can be connected to results in lesser immersive lessons, where rote learning is already prevalent among local schools as highlighted by Mohd Naser and Abd Aziz (2017) whose studies specifically view students' perceptions with regards to text selections for the literature. Without 
effective text selection, students are at risk of formulating least meaningful text engagement, leaving them frustrated and opting for an easier route, i.e. rote learning.

Items B7-B9 measured the perceived effectiveness of the materials in portraying the content (Table 5). Among the 34 respondents, the responses received from all three questions were of mixed opinions. On whether the content of the materials aid in instilling interest in literature, $62 \%$ agreed on the matter while $29 \%$ were neutral. The mean score is 3.71. Regarding the content's comprehensibility in the absence of supplementary materials, only $29 \%$ agreed while the majority, $47 \%$ were neutral on this subject with a score mean of 3.12. The comprehensibility of the material may be linked to the fact that most Malaysian students have poor ability in integrating and interpreting the information that they read in the text (Puteh et al., 2016). Lastly regarding the cultural acceptability of the content, despite the consensus being that the majority agrees, there was no majority with those in agreement and neutral at $47 \%$ each however it should be noted that $3 \%$ strongly agreed and only $3 \%$ disagreed wholly. This shows that the material meets one of the pedagogical criteria as set by Bousbai (2014) in selecting materials which is meeting the learner's cultural background which is a criterion alongside meeting the learner's linguistic proficiency and learner's literary background.

Table 5. Perceived Effectiveness of materials in content portrayal

\begin{tabular}{|c|c|c|c|c|c|c|c|}
\hline Item & & 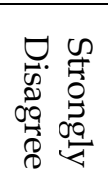 & 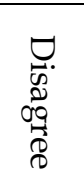 & 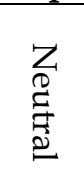 & 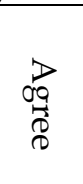 & 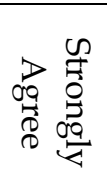 & 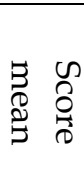 \\
\hline B7 & $\begin{array}{l}\text { The content of the literary } \\
\text { text provided by Ministry } \\
\text { can instil further interest } \\
\text { towards literature }\end{array}$ & $\begin{array}{l}0 \% \\
(0)\end{array}$ & $\begin{array}{l}3 \% \\
(1)\end{array}$ & $\begin{array}{c}29 \% \\
(10)\end{array}$ & $\begin{array}{l}62 \% \\
(21)\end{array}$ & $\begin{array}{l}6 \% \\
(2)\end{array}$ & 3.71 \\
\hline B8 & $\begin{array}{l}\text { The content of the literary } \\
\text { text provided by the } \\
\text { Ministry can be } \\
\text { understood on its own } \\
\text { without help of } \\
\text { supplementary materials }\end{array}$ & $\begin{array}{l}3 \% \\
(1)\end{array}$ & $\begin{array}{c}18 \% \\
(6)\end{array}$ & $\begin{array}{l}47 \% \\
(16)\end{array}$ & $\begin{array}{c}29 \% \\
(10)\end{array}$ & $\begin{array}{l}3 \% \\
(1)\end{array}$ & 3.12 \\
\hline B9 & $\begin{array}{l}\text { The content of the literary } \\
\text { texts provided by the } \\
\text { Ministry are culturally } \\
\text { acceptable } \\
\text { appropriate }\end{array}$ & $\begin{array}{l}0 \% \\
(0)\end{array}$ & $\begin{array}{l}3 \% \\
(1)\end{array}$ & $\begin{array}{l}47 \% \\
(16)\end{array}$ & $\begin{array}{l}47 \% \\
(16)\end{array}$ & $\begin{array}{l}3 \% \\
(1)\end{array}$ & 3.5 \\
\hline
\end{tabular}

Interestingly, it is found that most items are at an average level of perception regarding the content of the prescribed texts, probably hinting on tolerance towards the texts.

In order to tab further into teachers' perception on types of texts, Section C of the questionnaire, which contains nine questions, is divided into three aspects which are (1) the teachers' views on the use of foreign and local literary text when teaching literature in Malaysian Primary Schools, (2) the perceived impact of the 
literary texts on the students and (3) the perceived impact of literary texts on the lesson itself.

Table 6. Teachers' perceptions on the use of foreign and local literary text

\begin{tabular}{|c|c|c|c|c|c|c|c|}
\hline Item & & 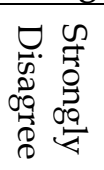 & 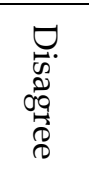 & 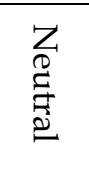 & 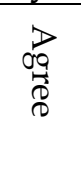 & 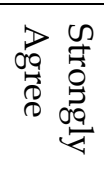 & 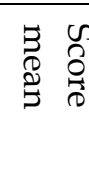 \\
\hline $\mathrm{C} 1$ & $\begin{array}{l}\text { Teaching and learning process can } \\
\text { be made more effective with the use } \\
\text { of local literary items }\end{array}$ & $\begin{array}{l}0 \% \\
(0)\end{array}$ & $\begin{array}{l}0 \% \\
(0)\end{array}$ & $\begin{array}{l}9 \% \\
\text { (3) }\end{array}$ & $\begin{array}{l}68 \% \\
(23)\end{array}$ & $\begin{array}{l}24 \% \\
(8)\end{array}$ & 4.15 \\
\hline $\mathrm{C} 2$ & $\begin{array}{l}\text { Teaching and learning process can } \\
\text { be made more effective with the use } \\
\text { of foreign literary items }\end{array}$ & $\begin{array}{l}3 \% \\
(1)\end{array}$ & $\begin{array}{l}21 \% \\
(7)\end{array}$ & $\begin{array}{l}44 \% \\
(15)\end{array}$ & $\begin{array}{l}27 \% \\
(9)\end{array}$ & $\begin{array}{l}6 \% \\
(2)\end{array}$ & 3.12 \\
\hline C3 & $\begin{array}{l}\text { The cultural context or origin of a } \\
\text { literary item does not affect the } \\
\text { students' understanding of the item }\end{array}$ & $\begin{array}{l}0 \% \\
(0)\end{array}$ & $\begin{array}{l}15 \% \\
\text { (5) }\end{array}$ & $\begin{array}{l}50 \% \\
(17)\end{array}$ & $\begin{array}{l}32 \% \\
\text { (11) }\end{array}$ & $\begin{array}{l}3 \% \\
(1)\end{array}$ & 3.24 \\
\hline
\end{tabular}

Items C1-C3 aimed to measure the teachers' perceptions on whether to use local or foreign literary texts when teaching literature in Malaysian Primary Schools. From the total number of 34 respondents who answered the survey, it can be seen that the majority of them prefer the use of local literary texts over foreign literary texts (Table 6 shows the responses for local texts). This supports the recommendation forwarded by Nambiar et al. (2020) for the use of local culturebased texts in creating familiarity, which helps tremendously in their learning and is suitable to them in terms of language level and demographics. It was noted that regarding whether or not the literary texts and materials are helpful in lessons, $68 \%$ of the respondents agreed while $9 \%$ were neutral in their opinion. On the subject of the relationship between cultural context or origins of a literary item and its effect on understanding of an item, $32 \%$ of the respondents believed that it did not affect the students' understanding of the literary text while $50 \%$ were neutral on this matter (Table 6). They suggest texts that are culturally attuned to the readers for an intrinsic effect. Sampled teachers observed the effectiveness of the current materials used in schools thus slightly contradicting the finding that local texts are preferred over foreign texts as the current set of materials used are foreign materials.

Results for item $\mathrm{C} 1$ in the survey provides a denotation of teachers' preference for the use of local literature texts as compared to foreign texts. Most of the respondents were divided in their responses; this can be seen in their neutral feedback on whether the prescribed materials are sufficiently good for classroom use. In fact, understanding the respondents' feedback on their preference of literature text is better understood if both items $\mathrm{C} 1$ and $\mathrm{C} 2$ are analysed together. Results indicate that local texts are more effective, supporting Brumfit (1985) criteria for text selection since the selection of prescribed reading texts ought to fit the readers' linguistic level, cultural and social expectations within the groups of learners. This selection will allow an effective process of meaning-making to occur since it is relative to students and their background. This is because the cultural context and origins of a text are important aspects that needed to be considered 
as put by Lotherington-Woloszyn (1988), who highlighted that learners find texts as uninteresting for failing to engage with them and turning things relatable despite the level of text readability. As such, when discussing the effectiveness of text usage for classroom purposes, one cannot afford to overlook the importance of cultural aspects when selecting texts. With that in mind, the current materials which are not of local origin may pose a problem to some and could be considered alongside the finding that most respondents do not agree that the cultural context or origin of a material does not affect the students' understanding of it based on C3.

Table 7. Perceived impact of the literary texts on the students' learning

\begin{tabular}{|c|c|c|c|c|c|c|c|}
\hline & Item & 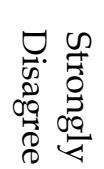 & 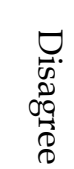 & 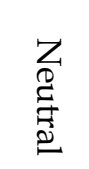 & $\begin{array}{l}\vec{D} \\
\underset{0}{0} \\
\overrightarrow{0}\end{array}$ & 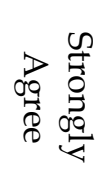 & 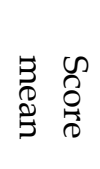 \\
\hline C4 & $\begin{array}{l}\text { The literary texts and materials } \\
\text { provided by the Ministry of } \\
\text { Education are meaningful to } \\
\text { students }\end{array}$ & $\begin{array}{l}0 \% \\
(0)\end{array}$ & $\begin{array}{l}0 \% \\
(0)\end{array}$ & $\begin{array}{c}38 \% \\
(13)\end{array}$ & $\begin{array}{l}56 \% \\
(19)\end{array}$ & $\begin{array}{l}6 \% \\
(2)\end{array}$ & 3.68 \\
\hline C5 & $\begin{array}{l}\text { The literary texts and materials } \\
\text { provided by the Ministry of } \\
\text { Education creates are enjoyable by } \\
\text { students }\end{array}$ & $\begin{array}{l}0 \% \\
(0)\end{array}$ & $\begin{array}{l}0 \% \\
(0)\end{array}$ & $\begin{array}{l}35 \% \\
(12)\end{array}$ & $\begin{array}{l}59 \% \\
(20)\end{array}$ & $\begin{array}{l}6 \% \\
(2)\end{array}$ & 3.71 \\
\hline C6 & $\begin{array}{l}\text { The literary texts and materials } \\
\text { provided by the Ministry of } \\
\text { Education provides room for more } \\
\text { creativity to be expressed in lessons }\end{array}$ & $\begin{array}{l}0 \% \\
(0)\end{array}$ & $\begin{array}{l}0 \% \\
(0)\end{array}$ & $\begin{array}{c}35 \% \\
(12)\end{array}$ & $\begin{array}{l}59 \% \\
(20)\end{array}$ & $\begin{array}{l}5 . \% \\
(2)\end{array}$ & 3.71 \\
\hline
\end{tabular}

Items C4-C5 measured the teachers' perceived impact of the literary texts and materials prescribed by the Ministry of Education literary text on the students' learning experience. Findings revealed that most respondents agreed that the literary texts used have positive impacts (Table 7). It is noted that the majority concurred on this $38 \%$ remained neutral. Students are less likely able to reflect and evaluate the text critically when they are not able to achieve or form a broad understanding of the text (Puteh et al., 2016; Deswila et al., 2021). On the matter of whether the literary texts and materials create an enjoyable lesson, the majority of the respondents agreed that it creates an enjoyable lesson. On the relationship between the selected texts and its provision for creativity to be expressed in lessons, $59 \%$ of the respondents agreed on this while $35 \%$ were neutral in their opinion with a mean score of 3.71. The material used currently in teaching literature are Artistic texts which comprise poems, prose, etc. hence showing that the materials used support the expression of creativity that is in line with the characteristics of the current materials used. 
Table 8. Perceived impact of literary texts on the lesson

\begin{tabular}{|c|c|c|c|c|c|c|c|}
\hline Item & & 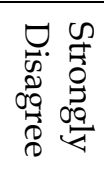 & $\begin{array}{c}\nabla \\
\nabla \\
0 \\
0 \\
09 \\
0 \\
0 \\
0\end{array}$ & $\begin{array}{l}Z \\
Z \\
\mathbb{Z} \\
\mathbb{Z} \\
2 \\
0\end{array}$ & $\begin{array}{l}\vec{D} \\
0 \\
\mathbb{D} \\
0\end{array}$ & 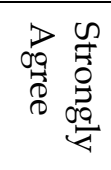 & 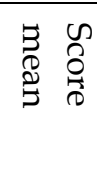 \\
\hline C7 & $\begin{array}{l}\text { The literary texts and } \\
\text { materials provided by the } \\
\text { Ministry of Education help } \\
\text { instil moral values in the } \\
\text { student }\end{array}$ & $\begin{array}{l}0 \% \\
(0)\end{array}$ & $\begin{array}{l}2.9 \% \\
(1)\end{array}$ & $\begin{array}{l}29.4 \% \\
(10)\end{array}$ & $\begin{array}{l}58.8 \% \\
(20)\end{array}$ & $\begin{array}{l}8.8 \% \\
\text { (3) }\end{array}$ & 3.74 \\
\hline C8 & $\begin{array}{l}\text { The literary texts and } \\
\text { materials provided by the } \\
\text { Ministry of Education } \\
\text { provide students a wider } \\
\text { range of knowledge that is } \\
\text { not available from other } \\
\text { subjects }\end{array}$ & $\begin{array}{l}0 \% \\
(0)\end{array}$ & $\begin{array}{l}0 \% \\
(0)\end{array}$ & $\begin{array}{l}35.3 \% \\
(12)\end{array}$ & $\begin{array}{l}58.8 \% \\
(20)\end{array}$ & $\begin{array}{l}5.9 \% \\
(2)\end{array}$ & 3.71 \\
\hline C9 & $\begin{array}{l}\text { The literary texts and } \\
\text { materials provided by the } \\
\text { Ministry of Education are } \\
\text { effective in catering to } \\
\text { students of mixed } \\
\text { proficiencies }\end{array}$ & $\begin{array}{l}0 \% \\
(0)\end{array}$ & $\begin{array}{l}2.9 \% \\
(1)\end{array}$ & $\begin{array}{l}38.2 \% \\
(13)\end{array}$ & $\begin{array}{l}55.9 \% \\
(19)\end{array}$ & $\begin{array}{l}2.9 \% \\
(1)\end{array}$ & 3.59 \\
\hline
\end{tabular}

Items C7-C9 aimed to measure the perceived impact of the literary texts and materials provided by the Ministry of Education on the students. From the total number of 34 respondents who answered the survey, it can be seen that a majority of them agree that the literary texts used have positive impacts on the students (Table 8). On the matter of text selection and its role as providing a wider range of knowledge that is not available from other subjects, the majority agreed on this while $35 \%$ chose to remain neutral. This does imply that the students have familiarized themselves with the material and its content hence their ability to accept the new range of knowledge attained. Lastly, Item C9 indicates that the majority agreed that the selection of literary texts is effective at providing students of mixed proficiencies while $38 \%$ were neutral on this.

\section{Conclusion}

Previous studies on text selection and assessment specifying for the teaching of literature in Malaysian schools either look into the aspect of effectiveness in general (e.g. Rashid, Vethamani \& Rahman, 2010) or students' perception and attitude on the text selection (e.g. Ghazali et al., 2009; Mohd Naser \& Abd Aziz, 2017), which brought about popular proposals for the use of local texts (e.g. Lim, 2018; Nambiar et al., 2020). What is missing from these research is the inside story on the effectiveness of the selected texts. Considering the teachers' perception on the effectiveness of the selected literary texts provides a research opportunity for further exploration. This research measured the perception of effectiveness of the prescribed texts and explored teachers' perceptions on the texts as part of their teaching syllabus in Malaysian Primary Schools. 
Since literary texts reflect the realities of human lives, cultures and civilisations, deliberate choices between using local or foreign literary texts is crucial because it involves students' ability to read, understand, examine, analyse and interpret these literary texts. When students are able to engage in these readings, it will enable them to engage with important questions about life (Yusoff, 2017). The findings provided a continuous evaluation of the current selection of textbook reading used in the teaching of literature in Malaysia which sadly suggests a reconsideration of changes in its selection. As such, this research proposes that teaching English literature using local literary texts is bound to be more effective than using foreign literary texts.

Future research might consider the use of group experimental design in order to prove such a claim. Not only selecting appropriate texts that fit young Malaysian school students have a longer effect on their proficiency, its selection may have direct impacts on nurturing a healthy reading culture, which is devastatingly poor in statistics. Instead of harnessing emotionally sensitive young minds, poorly selected texts are bound to shape parrots since young school students will have the tendency to opt out learning via rote learning. Future research should also consider approaching aspects within perceived effectiveness at prescribing the texts i.e. by exploring types of local teaching materials that are suitable with Malaysian primary school students, besides further exploring reasons for choosing local teaching materials. Finally, future research might also consider approaching these two aspects using qualitative analysis would also provide a rich understanding of using locally developed teaching materials, as suggested by Losekan and Godoy (2020) and Nambiar et al. (2020).

This study has led to several implications to the MoE and the ESL primary school teachers who are teaching English literature in Malaysian Primary Schools, which are discussed as follows. At the ministry level, this paper recommends two: one, for a provision of literary texts and materials that are culturally-appropriate, which allow students to understand their reading materials without using supplementary aids. This suggestion reiterates a study conducted by Nambiar et al. (2020) which focuses on speaking confidence. If the use of local texts can encourage speaking confidence, which is another level compared to reading skills, one can imagine the impact from using local texts as part of a reading programme would do for reading skills. As such, re-selecting a set of literary texts that are mostly made up of locally culture-based would enable better reading engagement between students and texts, allowing the potential for classroom engagement. Secondly, the MoE should also provide literary texts and materials that can arouse the student's interest towards literature, instilling moral values and catering to the ranges of proficiencies. Similarly, encouraging students' involvement in classroom participation ought to take into consideration their interest and level of potential for participation, leading towards a tendency for them to shy away, which contributes to greater readability. By endorsing a more suitable set of text selection that fits students' readability, this might lead to improved classroom activities and learning. This is because using a text with a foreign setting would reduce a probability for classroom engagement. At the teachers' level, this study encourages teachers to use literary texts and materials which are provided by MoE 
in order to instil students' interest in learning English literature. Not only will its learning incorporate students' ability to relate content with reading, it will also provide an outlet for cultural enrichment through life examples and events as featured in the materials.

\section{References}

Abdul Hamid, N. S., \& Mohd Shah, P. (2017). "The Effects of using Comic Strips in Improving English Reading Comprehension Skills in a low Proficiency class". Prosiding Konvensyen Kebangsaan Sekolah Kluster Kecemerlangan. Bahagian Pengurusan Sekolah Berasrama Penuh dan Sekolah Kecemerlangan.

Ain, N. (2019). Call for comprehensive study into decline in English proficiency among students. New Straits Times. Retrieved from https://www.nst.com.my/news/nation/2019/05/489779/call-comprehensivestudy-decline-english-proficiency-among-students-nsttv/2.1.3713.7286

Akyel, A., \& Yalcin, E. (1990). "Literature in the EFL class: A study of goal-achievement incongruence". ELT Journal 44(3), 174-180. https:// doi.org/10.1093/elt/44.3.174

Aziz, H. (2018). "Malaysia drops 9 spots in English proficiency ranking for non-native speakers". New Straits Times. Retrieved from https://www.nst.com.my/ education/2018/10/426949/malaysia-drops-9-spots-english-proficiencyranking-non-native-speakers

Aziz, A. H. A. A., Rashid, R. A, \& Zainudin, W. Z. W. (2018). The enactment of the Malaysian Common European Framework of Reference (CEFR): National master trainer's reflection. Indonesian Journal of Applied Linguistics, 8(2), 409-417.

Azman, H. (2016). "Implementation and Challenges of English language Education Reform in Malaysian Primary Schools". 3L: The Southeast Asian Journal of English Language Studies, 22(3), 65-78. http://doi.org/10.17576/3L-2016-2203-05

Bousbai, A. (2014). “Techniques for Selecting and Evaluating English Language Literary Texts". Al-Athar, 19, 7-14. https:// doi.org/10.12816/0008959

Brumfit, C. (1985). Language and literature teaching: From practice to principle. Oxford: Pergamon Press.

Decker, F. (2018). "How to average likert scales" Sciencing. Retrieved from https:// sciencing.com/average-likert-scales-6181662.html

Deswila, N., Kustati, M., Yusuf, Y. Q., Raja Harun, R. N. S., Besral, \& Rehani. (2021). Cultural contents in the ELT textbook prepared by the Indonesian Ministry of Education for secondary schools. Journal of Nusantara Studies, 6(1), 222-241. http://dx.doi.org/10.24200/jonus.vol6iss1pp222-241

Fischman, M. W. (2000). Informed consent. In B. D. Sales \& S. Folkman (Eds.), Ethics in research with human participants, 35-48. American Psychological Association.

Given, L. M. (2008). The SAGE Encyclopedia of Qualitative Research Method. Vol. 2. Los Angeles: Sage.

Ghazali, S. N., Setia, R., Muthusamy, C., \& Jusoff, K. (2009). "ESL students' attitude towards texts and teaching methods used in literature classes". English language teaching, 2(4), 51-56. https://doi.org/10.5539/elt.v2n4p51

Heberlein, T., \& Baumgartner, R. (1978). "Factors affecting response rates to mailed questionnaires: A quantitative analysis of the published literature". American Sociological Review, 43, 447-462. https://doi.org/10.2307/2094771

Ismail, H. H. (2019). "Literature and gender equality as national sustainable goals." Trends in Social Sciences, 1(3), 16-24. 
Kaur, P., \& Mahmoor, N. (2014). “Examining the role of the English literature component in the Malaysian English curriculum". Procedia - Social and Behavioral Sciences, 134, 119-124. https://doi.org/10.1016/j.sbspro.2014.04.229

Khan, M. S. R., \& Alasmari, A. M. (2018). "Literary Texts in the EFL Classrooms Applications. Benefits and Approaches". International Journal of Applied Linguistics, 7(5), 167-179. http://dx.doi.org/10.7575/aiac.ijalel.v.7n.5p.167

Lasekan, O., \& Godoy, M. (2020). “Towards a Sustainable Local Development of Instructional Material: An Impact Assessment of Locally Produced Videos on EFL Learners' Skills and Individual Difference Factors". Frontiers in Psychology, 11, 112. http:/ /dx.doi.org/10.3389/fpsyg.2020.02075

Lim, J. W. (2018). “Localizing English literature as a school subject: A Malaysian experience". Asia Pacific Journal of Education, 38, 151-163. https:// doi.org/10.1080/02188791.2018.1460254

Lima, C. (2010). "Selecting Literary Texts for Language Learning”. Journal of NELTA, 15(12), 110-113. https:// doi.org/10.3126/nelta.v15i1-2.4616

Lotherington-Woloszyn, H. (1988). “On Simplified and Simplifying Materials for ESL Reading". TESL Talk, 18(1), 112-122.

Ministry of Education Malaysia. (2010). Malaysia Education Blueprint 2013-2025. Putrajaya: Bahagian Pembangunan Kurikulum.

Mihat, W., Azman, H., \& Or, K. S. (2018). “Bringing Reading Research in Multilingual Nusantara into a new direction through eye-tracking". Journal of Nusantara Studies (JONUS), 3(2), 107-123. http://dx.doi.org/10.24200/jonus.vol3iss2pp107-123

Mohd Naser, S. H., \& Abd Aziz, A. (2017). "Students' Perceptions of the text selection in the literature component". National Pre-University Seminar 2017 (NpreUS2017). RHR Hotel, Bangi Malaysia. 23 August 2017. E-ISBN: 978-967-2122-11-1.

Muhammad, S. N., Latiff Azmi, M. N., \& Hassan, I. (2020). "Reading Interest and its relationship with reading performance: A study of English as second language learners in Malaysia". Humanities \& Social Sciences Reviews, 7(6), 1154-1161. https:// doi.org/10.18510/hssr.2019.76165

Mukundan, J. (2007). “Evaluation of English Language Textbooks: Some Important Issues for Consideration". Journal of NELTA, 12(1\&2), 80-84. https://doi.org/10.3126/nelta.v12i1.3432

Mustaffar, S. N. F., Baharuddin, N. Q., \& Yunus, M. M. (2019). “Tweet Teach to Enhance Reading Skill among Low Proficiency Pupils". International Journal of Academic Research in Business and Social Sciences, 9(1), 609-619. https://doi.org/10.6007/IJARBSS/v9-i1/5462

Nambiar, R. M. K., Ibrahim, N., Hashim, R. S., Yasin, R. M., Azman, H., Yusof, N. M., Ramli, R., \& Mustaffa, R. (2020). “Impact of Local Culture-Based Reading Materials on Students' Skill Development and Confidence in English". Universal Journal of Educational Research, 8(2), 445-453. https:/ / doi.org/10.13189/ujer.2020.080215

Papalia, A. (1987). “Interaction of reader and text”. In W. Rivers (Ed.) Interactive language teaching. Cambridge: Cambridge University Press.

Peekabook. (2014). KSSR - Changes in Everything Old. Retrieved August 7, 2019, from https:// peekabook.com.my/blog/kssr-changes-in-everything-old/

Prowse, P. (2002). “Top ten principles for teaching extensive reading: A response”. Reading in a Foreign Language, 14(2), 142-145.

Puteh, M., Mohd Zin, Z., \& Ismail, I. (2012). “Reading Performance of Malaysian Students across gender in PISA 2012." 3L: The Southeast Asian Journal of English Language Studies, 22(2), 109-121. http:/ / doi.org/10.17576/3L-2016-2202-08 
Radzuwan, A. R. (2011). Vocabulary Learning among less proficient young adults using children's stories1. Mextesol Journal, 35(1), 1-11.

Rashid, R. A., Vethamani, M. E., \& Rahman, S. B. A. (2010). Approaches Employed by Teachers in Teaching Literature to Less Proficient Students in Form 1 and Form 2. English Language Teaching, 3(4), 87-99.

Rashid, R. A., Abd Rahman, S. B., \& Ismail, H. H. (2020). The Teaching of Literature to Less Proficient Students. Penerbit UniSZA: Kuala Terengganu.

Rashid, R. A., Abdul Rahman, S. B., \& Yunus, K. (2017). Reforms in the policy of English language teaching in Malaysia. Policy Futures in Education, 15(1), 100-112.

Saito, Y., Horwitz, E. K., \& Garza, T. J. (1999). “Foreign Language Reading Anxiety”. The Modern Language Journal, 83(2), 202-218. https://doi.org/10.1111/00267902.00016

Sewell, E. J. (2003). Students' Choice of Books during Self-Selected Reading. EDRS opinion papers. Retrieved September 23, 2008 from http:/ / search.ebscohost.com/login.aspx?direct=true\&db=eric\&AN=ED476400\& site=ehost-live

Sulaiman, T., Mohd Ayub, A. F., \& Sulaiman, S. (2015). “Curriculum Change in English

Language Curriculum Advocates Higher Order Thinking Skills and Standards-Based Assessment in Malaysian Primary Schools". Mediterranean Journal of Social Sciences, 6(2), 494-500. http:/ / dx.doi.org/10.5901/mjss.2015.v6n2p494

Suliman, A., \& Yunus, M.M. (2014a). “A Glimpse on the Re-Introduction of English Literature in Malaysian Secondary Schools". International Journal of Languages and Literatures, 2(2), 151-164.

Suliman, A., \& Yunus, M.M. (2014b). “The Re-Introduction of English Literature Subject in Malaysian Secondary Schools; Urban versus Rural Teachers". Journal of Education and Human Development, 3(2), 943-955.

Thirunavukarasu, I., \& Raja Harun, R. N. S. (2021). The effects of cultural based text types in reading comprehension. Journal of Nusantara Studies, 6(1), 1-23. http:/ / dx.doi.org/10.24200/jonus.vol6iss1pp1-23

Trochim, W. M. K. (2020). Research Methods Knowledge Base. Retrieved from https://conjointly.com/kb/descriptive-statistics/

Wright, K. B. (2017) "Researching Internet-Based Populations: Advantages and Disadvantages of Online Survey Research, Online Questionnaire Authoring Software Packages, and Web Survey Services". Journal of Computer-Mediated Communication, 10(3). https:/ / doi.org/10.1111/j.1083-6101.2005.tb00259.x

Yusuf, N. (2017). "Knowledge culture: In defence of arts and humanities." New Straits Times. Retrieved from https://www.nst.com.my/opinion/letters/2017/11/300651/knowledgeculture-defence-arts-and-humanities

Zulaily, N., Aryati, A., Nor Saidah, A. M., Rahmah, M. A., Shahril, M. R., Sharifah, W. W. S. S., Tarek, W., Engku, F. H. S. A. \& Amran, A. (2017). “Influence of School Location within Districts of Terengganu on Body Weight Status among School Adolescents". International Journal of Academic Research in Business and Social Sciences, 7(6), 1166-1178. http://dx.doi.org/10.6007/IJARBSS/v7-i6/3200 


\section{APPENDIX}

\section{SECTION A: DEMOGRAPHICS}

1. Please select your gender.

- Male

- Female

2. How long have you been teaching at your current school?

- Less than 3 years

- 3-5 years

- 6-10 years

- More than 10 years

3. How long have you been teaching English at schools?

- Less than 3 years

- 3-5 years

- 6-10 years

- More than 10 years

4. How long have you been teaching English literature in school?

- Less than 3 years

- 3-5 years

- 6-10 years

- More than 10 years

5. What type of schools have you taught English in?

- SK

- $\operatorname{SJK}(\mathrm{C})$

- $\operatorname{SJK}(\mathrm{T})$

- Both National and National Type School

6. Which year(s) do you teach?

\section{SECTION B: EFFECTIVENESS OF TEACHING MATERIALS USED IN TEACHING OF LITERATURE}

Based on a scale of 1 to 5 (where 1 is Strongly Disagree and 5 Strongly Agree), choose the best to reflect your opinions.

1. Students actively participate in the process of understanding the meaning of materials.

$$
\begin{array}{lllll}
1 & 2 & 3 & 4 & 5
\end{array}
$$

2. Students are stimulated to work with classmates in deciphering the literary item

$$
\begin{array}{lllll}
1 & 2 & 3 & 4 & 5
\end{array}
$$

3. The materials are able to enhance more than one language skills in the students.

$$
\begin{array}{lllll}
1 & 2 & 3 & 4 & 5
\end{array}
$$

4. Teachers can plan a lesson easily with the provided materials.

$\begin{array}{lllll}1 & 2 & 3 & 4 & 5\end{array}$

5. Literary materials help teachers to stimulate use of target language. 


$$
\begin{array}{lllll}
1 & 2 & 3 & 4 & 5
\end{array}
$$

6. Materials used support the teaching objectives of the teacher.

$$
\begin{array}{lllll}
1 & 2 & 3 & 4 & 5
\end{array}
$$

7. The content of the literary text provided by the Ministry can instil further interest towards literature.

$\begin{array}{lllll}1 & 2 & 3 & 4 & 5\end{array}$

8. The content of the literary text provided by the Ministry can be understood on its own without any help of supplementary materials.

\section{$\begin{array}{lllll}1 & 2 & 3 & 4 & 5\end{array}$}

9. The content of the literary texts provided by the Ministry are culturally acceptable and appropriate.

$\begin{array}{lllll}1 & 2 & 3 & 4 & 5\end{array}$

\section{SECTION C: TEACHERS PERCEPTIONS ON THE LITERARY TEXTS USED IN TEACHING OF LITERATURE}

1. Teaching and learning process can be made more effective with the use of local literary items.

$\begin{array}{lllll}1 & 2 & 3 & 4 & 5\end{array}$

2. Teaching and learning process can be made more effective with the use of foreign literary items.
23
4
5

3. The cultural context or origin of a literary item does not affect the students' understanding of the item.
1
2
34
5

4. The literary texts and materials provided by the Ministry of Education are meaningful to students.
1
2
34
5

5. The literary texts and materials provided by the Ministry of Education are enjoyable by students.
12
34
5

6. The literary texts and materials provided by the Ministry of Education provides room for more creativity to be expressed in lessons.
1
2
3
4
5

7. The literary texts and materials provided by the Ministry of Education help instil moral values in the students.
1
2
34
5

8. The literary texts and materials provided by the Ministry of Education provide students a wider range of knowledge that is not available from other subjects
1
23
4
5

9. The literary texts and materials provided by the Ministry of Education are effective in catering to students of mixed proficiencies.

$\begin{array}{lllll}1 & 2 & 3 & 4 & 5\end{array}$ 